Â l'intersection des discours de spécialité :

hétérogénéité et unité

\title{
What are genres and should we teach them?
}

\section{Tony Bex}

\section{(2) OpenEdition \\ Journals}

Electronic version

URL: http://journals.openedition.org/asp/1791

DOI: 10.4000/asp.1791

ISBN: 978-2-8218-0414-2

ISSN: 2108-6354

Publisher

Groupe d'étude et de recherche en anglais de spécialité

\section{Printed version}

Date of publication: 30 November 2010

Number of pages: 5-18

ISSN: 1246-8185

Electronic reference

Tony Bex, «What are genres and should we teach them? », ASp [Online], 58 | 2010, Online since 30 November 2013, connection on 02 November 2020. URL : http://journals.openedition.org/asp/1791 ; DOI : https://doi.org/10.4000/asp.1791

This text was automatically generated on 2 November 2020.

Tous droits réservés 


\title{
What are genres and should we teach them?
}

\author{
Tony Bex
}

1 The questions posed in the title of this paper are not intended to be merely rhetorical. The first reflects my sense of unease about the ways in which genres have been characterised in recent years. In particular, the terms "genre" and "discourse" have often been used interchangeably, whereas I believe they are better used to represent different levels of generality. The second question relates to a moral issue. Some characterisations of discourses and the genres with which they are associated see them as essentially (socially) divisive. It behoves us, therefore, to consider whether we wish to contribute to such divisiveness.

2 The first citation for genre in the OED is "a. Kind; sort; style". Interestingly, however, the second citation is "b. spec. A particular style or category of works of art; esp. a type of literary work characterized by a particular form, style, or purpose." And this usage actually predates the more common usage by nearly fifty years. ${ }^{1}$ I am not entirely sure when it became current in linguistic studies, but I would guess that it would have been in the mid-1970s through the influence of Halliday's interest in the social nature of language (Halliday 1978). However, the study of text types had been a central concern in the developing world of ESP, with John Swales as a particularly assiduous researcher in the field (Swales 1971). Nevertheless, by a curious reversal in the development of their respective interests, Hallidayan linguists became increasingly interested in the structures of generic text types, while Swales investigated the communities which "owned" the genres he was interested in. In this paper, then, I intend to explore the (often unacknowledged) tension between the study of genres as a way of understanding how a language community speaks to itself, and the study and teaching of genres as a way of empowering students to develop specific educational and professional skills. I shall also be suggesting that the former study tends to see genres as "leaky", while the latter sees them as more rigid. I shall, however, start by tracing the development of a particular discourse and showing why the terms "discourse" and "genre" need to be distinguished. 


\section{Development of English literature as a discipline}

After the Glorious Revolution in 1688, there was a felt need to legitimise the new regime in England. One way of doing this was by crying up the achievements of English learning on the grounds that a cultured nation was also a secure nation. There was, however, some dispute as to whether this learning was best represented in the translations and imitations of the classics, or in the more modern forms of literature associated with the "new philosophy" of Descartes, Hobbes and Locke. This dispute was most famously recorded by Swift in The Battle of the Books (1703/5). Initially, the Antients appeared to have won the field, but their victory was complicated by the Act of Union (1707) which created a common parliament for England and Scotland. The needs of nationhood were no longer merely English, but now encompassed the new British nation which required a sense of corporate identity. These needs were accomplished in various ways, but one of the more interesting was the formation of a canon of literature in English of which the whole nation could be proud.

Kramnick (1998) has argued that this was driven by a number of competing interests.

Although the Antients were the initial victors, their supporters tended to come from the Tory interest and, when this collapsed at the accession of George I (1714), the opposing Whigs took control of the cultural agenda disseminating their ideas through such journals as Addison's Spectator. Addison himself was a staunch supporter of the philosophy of Locke, but he was also instrumental in popularising "polite" learning which necessarily included knowledge of the classical writers. It seems, then, that a curious inversion took place whereby to be well-read no longer required the arduous learning of Greek and Latin. The classics became common property and therefore, in the parlance of the earlier debates, modern. However, concurrently with this development, a number of scholars were re-discovering the English literary heritage as part of their programme to establish a distinctly British cultural identity. The burgeoning print culture was simultaneously flooding the market with books and the old optimism surrounding the spread of culture was slowly being replaced by a sense of alarm at the vulgarisation of literature. This tension can be observed in oldmixon (1728) who praises the development of refinement while claiming that it is an "insufficiently rigorous way of understanding the properties of literature" (in Kramnick 1998: 31). The scholars reacted to this vulgarisation by taking the concept of literature out of the public sphere and ringing it round with scholarship (or pedantry). As Lipkin (2005: 496) has observed:

No single set of critical principles could encompass such diverse groups and interests [as existed in the later eighteenth century]. Nevertheless, the power of critics continued to grow. "Nation" and "literature", two terms whose meanings were shifting, combined to produce "English literature", a compelling new phrase. [...] [R]eaders of Johnson's Prefaces and Warton's History could take pride in a collective achievement or artistic supremacy that bound Britons together.

The point about this brief discussion ${ }^{2}$ is to suggest that particular discourses are never "clean". It would be legitimate to argue that the processes I have been discussing developed from an overarching attempt to construct a discourse of nationhood, but which subsumed within it a lesser discourse of "English literature" that proved to be elitist and professional and which had its ultimate apotheosis in the creation of university departments of English in the nineteenth century. 
6 But if it is difficult to establish boundaries between discourses, it is even more problematic to identify those genres that are associated with them coherently. While we may wish to assert that there is, in some sense, a "discourse" of English literature, the genres that have grown out of this discourse are multifarious and share many of their characteristics with other, related, genres. Within the academy, there are the various learned journals which are stylistically similar to other journals within the humanities. There are also textbooks which draw on the discourses of education, and these can range from works produced for undergraduate and high school students to such productions as the Literature for Dummies guide. On the periphery, there are such productions as The Times Literary Supplement or The New York Review of Books which, although dedicated to literary matters, also share certain characteristics with other works of journalism. Are these latter, then, hybrids which require multiple levels of description, or can they be assigned to specific genres, and if so, which? I admit that I cannot hope to answer these questions, but I shall try to outline some hints as to how the questions can be approached.

7 This growing interest in the relationships between discourses and their associated genres has been noted by Tony Dudley-Evans and Maggie Jo St. John. In their epilogue to Developments in English for Specific Purposes (1998), they argued that ESP was entering a new and more critical engagement with its object of study. In particular, they noted an ideological awareness on the part of its practitioners who set out to challenge the norms of the educational institutions they inhabited. They further claimed that this development was worrying. A recent example of this can be seen in Bhatia's article in English for Specific Purposes when he states: "The study emphasizes the need to go from text to context in order to undertake a comprehensive and critical view of discursive practices" (2008: 161). This project seems to me both eminently worthwhile but also monumental in its ambition. I have suggested that the study of linguistic genres can be dated to the early 70 s and I think we can see a parabolic effect in which the ferment of ideas surrounding the Foucauldian notions of discursive practices were adopted by linguists and ESP specialists and then narrowed down to the particular investigation of specific genres (e.g., Swales 1990), but which are now opening up to the kind of wider concerns indicated by Bhatia.

8 Foucault's (1972: 117) definition of discursive practices proceeds by a curious indirection:

[...] what we have called "discursive practice" can now be defined more precisely. It must not be confused with the expressive operation by which an individual formulates an idea, a desire, an image; nor with the rational activity that may operate in a system of inference; nor with the "competence" of a speaking subject when he constructs grammatical sentences; it is a body of anonymous rules, always determined in the time and space that have defined a given period, and for a given social, economic, geographical, or linguistic area, the conditions of operation of the enunciative function.

9 In the preceding pages, it seems clear that Foucault is largely referring to sets of linguistic practices, but in later analyses "discursive practices" tended to include all kinds of symbolic acts. From the perspective of the practising linguist this latter definition was clearly too all-encompassing to be useful. Todorov (1976: 162) offered a more useful formulation when he argued: "In a society, the recurrence of certain discursive properties is institutionalised, and individual texts are produced and perceived in relation to the norms constituted by this codification." 
10 Although Todorov was referring to types of literary discourses, it was clear that this characterisation could be applied across disciplines. Of course, ESP teachers had been aware of the differences between text types for some time, but they now had a more useful tool with which to analyse these differences and place them in a wider context. Research therefore diversified into two broad areas: specific investigation into groups of texts which identified their similarities, and attempts to characterise the communities which produced such texts. Of course, these two groups overlapped, but for the purposes of this paper, I intend to distinguish them.

\section{Genre investigation}

11 Initially, the investigation of genre formation was derived from Halliday's work on register. A register was identified by a set of lexicogrammatical forms which manifested particular configurations of field, tenor and mode (Halliday 1978; Halliday \& Hasan 1989; Martin 1992; Leckie-Tarry 1995). Broadly speaking, the field identified what the text was about; the tenor the relationships between the text creator and its audience; and the mode the material nature of the text (i.e., written/spoken, ${ }^{3}$ full clauses vs. abbreviations, etc.). It was further claimed that register choices signal their context of interpretation. This latter claim was difficult to sustain given that identical linguistic formations were likely to be interpreted quite differently depending on their context of reception. So, for example, a sign "Danger of Death" would mean one thing when attached to an electricity sub-station and something quite different when attached to a teenager's door. Nevertheless, the development of register theory was a useful analytical tool which could help ESP researchers identify a number of the salient features of the texts they were investigating.

The relative failure to identify a sufficiently significant number of shared features between groups of texts which appeared to perform similar functions led to a surge of interest in genre studies. This interest was apparent in work done by Hasan (Halliday \& Hasan 1989: 63ff) where she claimed that individual texts contained a Generic Structure Potential. A GSP, in this formulation, can only be realised at the completion of the interaction. By analysing a series of shopping exchanges, she noted both the similarities in the language used and the successful social outcome of the interaction. She, therefore, came to the conclusion that genres arose because they were embedded in recurrent cultural contexts. Although persuasive, her arguments had a certain circularity in that it was not clear whether the choice of language was constitutive of the social context, or whether the social context determined the choice of language. Also, there seemed to be a missing middle in that the texts themselves only achieved meaning in their contexts, in which case textual analysis could never, on its own, establish the meaning of a text or group of texts. But this is not surprising given that meaning is, by its nature, indeterminate until it has been confirmed by the participants in the exchange. As Roy Harris (1998: 21) has observed:

[...] the signs that occur in first order communication are those that the participants construe as occurring, and what is signified is what the participants construe as having been signified. There is no higher court of appeal.

13 Nevertheless, the indissoluble link between language and context had been firmly established. 
14 At the same time, other linguists were investigating the rhetorical organisation of texts in greater detail. Bhatia (1993), for example, looked at the structure of academic introductions, observing a number of stepped sequences which seemed to be shared between all the introductions he studied, and Swales (1996) identified a shared set of moves in his discussion of the academic submission letter. Again, these analyses were satisfactory as far as they went, but they still fell short of offering us a clear theoretical account of genre. What, for example, was the relationship between academic introductions and non-academic introductions, or submission letters and other letters? Were the former to be regarded as sub-genres, or genres in their own right?

From the perspective of the ESP teacher, these may seem rarified questions, but a narrow concentration on the surface features of particular texts can have dangerous consequences, and this is nowhere more apparent than in the field of parody. Parody is, by its nature, subversive and unsettling since it mimics the genre it is parodying. However, it is also highly pertinent to my enquiry because it confirms the existence of genres while paradoxically calling into question any theoretical account we may give of the phenomenon.

16 I can best illustrate this by considering the case of the Sokal affair. In the Spring/ Summer 1996 issue of Social Text, Alan Sokal (Sokal and Bricmont 1998: 199), a physicist at New York State University, published a paper entitled "Transgressing the Boundaries: Towards a Transformative Hermeneutics of Quantum Gravity." ${ }^{4}$ In it, he derided;

The dogma imposed by the long post-Enlightenment hegemony over the Western intellectual outlook that there exists an external world, whose properties are independent of any individual human beings and indeed of humanity as a whole: that these properties are encoded in "eternal" physical laws; and that human beings can obtain reliable, albeit imperfect and tentative, knowledge of the laws by hewing to the "objective" procedures and epistemological structures prescribed by the (so-called) scientific method.

17 Almost simultaneously, he published an article (1996: 62) announcing that it was a parody, and that he wished to establish whether:

A leading North American journal of cultural studies - whose editorial collective includes such luminaries as Frederic Jameson and Andrew Ross - [would] publish an article liberally salted with nonsense if (a) it sounded good and (b) it flattered the editors' ideological preconceptions.

18 Although the furore surrounding this event is interesting in its own right, I shall concentrate only on the implications it has for genre theory. Sokal's own account (1996: 1-2) of how he constructed the article is revealing:

Like the genre it is meant to satirize - myriad examples of which can be found in my reference list - my article is a melange of truths, half-truths, quarter-truths, falsehoods, non-sequiturs, and syntactically correct sentences that have no meaning whatsoever [...] I also employed some other strategies in the genre: appeals to authority in lieu of logic; speculative theories passed off as established science; strained and even absurd analogies; rhetoric that sounds good but whose meaning is ambiguous; and confusion between the technical and everyday senses of English words.

19 Effectively, he is arguing that he copied the surface features of a particular generic type of writing.

Clearly, he was so successful that he managed to bamboozle the editors. ${ }^{5}$ However, it is worth imagining how they might have approached their task. Initially, they would have 
identified the text as a communicative event. Then, following the processes suggested by Hasan and Bhatia (above), they would have assigned it to a register. Various lexicogrammatical and rhetorical features would confirm that it was an academic paper, e.g., heavy nominalisation, prolific use of referencing and the moves in argumentation which set out a set of hypotheses which the paper intends to refute. of course, these features do not guarantee the intellectual validity of the argument being presented, but they carry a reasonable degree of presumption that the article is intended seriously. And, from the editors' own ideological perspective, this presumption is reinforced by such phrases as "the dogma imposed by the long postEnlightenment hegemony over the Western intellectual outlook."

21 My reading of the affair, then, is that the editors were not acting in bad faith, but were generally fooled by the successful manipulation of a set of generic devices. And this view is borne out both by some of the reactions to the article on the web, and by Alan Ross's own defence. A particularly interesting posting came from Mike Sosteric: ${ }^{6}$

The way I see it, and please correct me if I am wrong, there are two questions that need to be addressed here. These are 1) does the use of thick and impenetrable jargon invalidate inquiry? and 2) does publication of an invalid piece of scholarship prove anything about the epistemic or ontological security of a specific discipline? The answer to the first question must be no. Any established scholarly discipline will have a well developed and impenetrable wall of jargon designed to deter both the layman and other professionals and to create a professional enclave. It's really an old game of survival of the professions. Doctors need a license and must understand medical jargon, lawyers pass the bar (and we all know the impenetrability of legalese), and postmodernists learn POMOSPEAK. Mike Sosteric (socjourn@gpu.srv.ualberta.ca) 21 May 1996

This makes no mention of the intellectual content of the argument, but is very clear on the gate-holding properties of appropriate language. Alan Ross, however, was rather more circumspect. He starts by saying: ${ }^{7}$

Not knowing the author or his work, we engaged in some speculation about his intentions, and concluded that this article was the earnest attempt of a professional scientist to seek some kind of affirmation from postmodern philosophy for developments in his field.

Leaving aside the failure to confirm both the provenance of the author and the quality of the science, this does suggest that the editors were indeed seduced by the linguistic choices, and this impression is partially confirmed when he goes on to say:

Sokal's assumption that his "parody" [and the scare quotes are interesting here] struck a disreputable chord with the woozy editors of Social Text is ill-conceived. Indeed, its status as parody does not alter substantially our initial perception of, and our interest in, the piece as a curio, or symptomatic document. Of course, the whole affair may say something about our own conception of how physicists read philosophy [...].

There is a twist in the tale here ${ }^{8}$ which contains the merest hint that Ross had noticed some features that were inappropriate, but not such that he felt the need to investigate further. ${ }^{9}$

There are, I think, two cautionary tales here. The first is that a concentration on the surface features of a text, or group of texts cannot have anything to say about the intellectual validity of that text. From the point of view of ESP teachers this should be of some, if small, concern. Of course, it is extremely unlikely that their students will be able to produce such a brilliant parody as that of Sokal but it is possible that they will 
be presented with sample texts of dubious science. This, though, I believe to be a technical problem which can be overcome so long as the texts are guaranteed by the departments which use them in good faith.

The second problem strikes at the heart of the theoretical issues of what is a genre. If the editors of Social Text genuinely believed that the Sokal text was an example, albeit marginal, of the subgenre of academic writing in postmodern philosophy, then it would seem to belong to that genre, at least according to all the markers we have so far identified. However, on learning that it was a parody, we necessarily have to re-assign it to some other genre since it is clearly not a work of such philosophy. The obvious solution would seem to be to establish a genre of parody but, given the sheer diversity of parodies, this would be impossible. Of course, they could be re-classified as some kind of subgenre of literature. But if we were to do this we are left in the uncomfortable situation of acknowledging that parodies are, in some sense, parasitic on those genres they parody, without actually belonging to them. Parody, then, calls into question the functional efficacy of textual generic markers and suggests that we should look elsewhere if we want to establish what constitutes a genre.

\section{Are genres social constructs?}

However, similar problems seem to occur when attempts were made to define genres largely according to their users. One of the more interesting attempts was made by Swales (1990: 24ff) where he referred to discourse communities who possessed:

[1] a broadly agreed set of common public goals;

[2] mechanisms of intercommunication among members;

[3] participatory mechanisms primarily to provide information and feedback;

[4] one or more genres in the communicative furtherance of its aims;

[5] some specific lexis;

[6] a threshold level of members with a suitable degree of relevant content and discoursal expertise. which would account for the historical development and change of given genres. However, it did capture the essential insight that genres were social, as much as linguistic, constructs. Swales (1993) later acknowledged other problems. In particular, he recognised that there may be communities who shared common interests but who never communicated with each other.

Another researcher, working in ESP, also adopted a more person-based approach. Discussing the production of scientific research papers, Paltridge (1995: 400) argued that they had to be produced under a set of felicity conditions:

The research, therefore, must be carried out and reported on by the right person, in the right place and at the right time, with a specific intent, or else it would simply "not work". The felicity conditions for communicative events are, thus, essentially nonlinguistic. The circumstances of the text, furthermore, are genre-assigning even when the elements are essentially untypical.

He goes on to state that the recognition of "prototypical" texts which represent the subgenre to which they belong is based on "pragmatic and perceptual, rather than linguistic, aspects of communicative events" (1995: 403). This formulation works well within the narrow band of laboratory-based scientific papers since it defines the discourse community in relatively narrow terms and notes that there are specific 
power relations in operation. However, it cannot accommodate the kinds of papers that appear in Social Text, nor, I suspect, much business communication where authority is more widely dispersed.

Both Swales and Paltridge, in their different ways, draw the boundaries of discourse communities too tightly. Barton (1994: 57) was clearly frustrated by the apparent intractable nature of this problem, arguing that:

discourse community can refer to several overlapping groups of people: it can refer to the people a text is aimed at; it can be the people who read a text; or it can refer to the people who participate in a set of discursive practices both by reading and by writing. People's preferences in how they wish to define it are dictated partly by their purpose.

However, this characterisation falls short of a definition as he admits in his last sentence, and leaves us no closer to an understanding of the social dimensions of those groups of people who both recognise and create generic texts.

\section{Concluding remarks}

So far, I have argued that simple, or indeed even complex, linguistic descriptions of sets of texts, although interesting in their own right, are unable to establish a sufficient number of similarities between texts that are supposed to form a genre. In particular, I have attempted to show that the existence of parodies tends to render such attempts as theoretically (though not pragmatically) impossible. I have also suggested that the more ethnographic approaches to genre have their own problems. This would seem to presage a rather bleak future for genre studies. However, I think there are plenty of grounds for optimism so long as we acknowledge the contingent nature of the project. On the one hand, there are the methodological demands of the ESP syllabus and classroom; on the other, the logical demands of a coherent theory, and although methodology should be informed by theory, it need not be dominated by it.

My own model (and it certainly has not yet achieved the status of a theory) of how written genres operate in society can be illustrated from the following table.

Table 1. Model adapted from Bex (1996: 85)

\begin{tabular}{|c|c|c|}
\hline LANGUAGE USERS & LANGUAGE-IN-ACTION & $\begin{array}{l}\text { LANGUAGE-IN- } \\
\text { OBSERVATION }\end{array}$ \\
\hline $\begin{array}{l}\text { All speakers of the } \\
\text { language }\end{array}$ & $\begin{array}{l}\text { Discourses (e.g., Literature, Advertising, Business, Law, } \\
\text { Education, etc.) }\end{array}$ & Textual Aggregations \\
\hline \multirow[t]{2}{*}{$\begin{array}{l}\text { Discourse } \\
\text { Networks }\end{array}$} & $\begin{array}{l}\text { Genres (e.g., Novels, Advertisements, Contracts, Text } \\
\text { Books, etc.) }\end{array}$ & \\
\hline & $\begin{array}{l}\text { Specialist subgenres (e.g., epistolary novels, small ads, } \\
\text { insurance contracts, geography textbooks, etc.) }\end{array}$ & Text Types \\
\hline Readers/Writers & $\begin{array}{l}\text { Registers (e.g., particular novels, ads., insurance } \\
\text { contracts, text books, etc.) }\end{array}$ & Texts \\
\hline
\end{tabular}




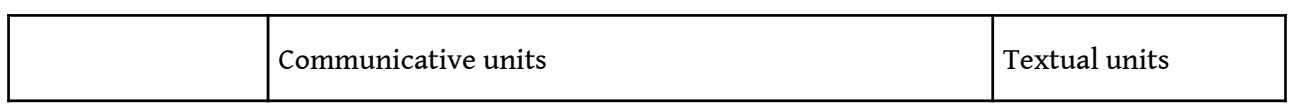

The right hand column represents the essential materiality of the language, and is typically the preserve of the professional linguist. The left hand column is an attempt to capture the people who are involved in interpreting texts. They, as individuals, identify the textual units as communicative units which cohere in such a way as to create a particular text.

The nature of that text is, however, provisional until it has been verified in some way through other readers. Such verification can take place in a variety of ways. It may involve immediate discussion with a friend or colleague. But it is more likely to be the result of a learned process in an educational setting. So, for example, we distinguish novels from histories in part because we have been taught such a distinction at school. I have referred to such readers as a discourse network, having borrowed the idea from Lesley Milroy's work on language maintenance. She identified two broadly distinct social networks: those whose members remained in close and frequent contact, and those whose contact was intermittent and she observed that the former (or close-knit network) tended to have their linguistic norms reinforced and were slow to adopt language change while the latter were more open to such change. I would suggest that the same is true for discourse networks.

Figure 1. Model adapted from Milroy (1987: 20)
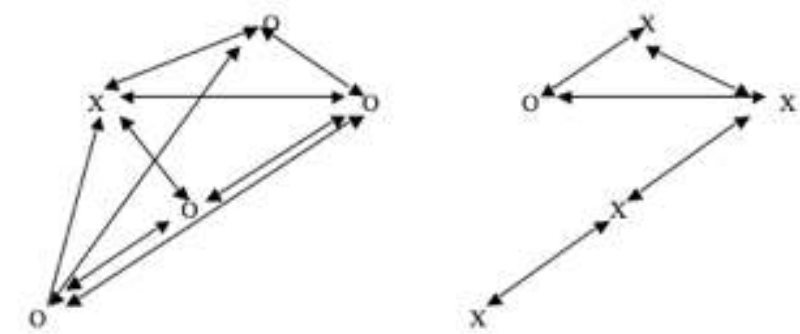

In these diagrams $\mathrm{X}$ represents a discourse network, while $\mathrm{O}$ represents the individuals who are members of it. The figure on the left stands for a tightly-knit discourse network, such as the editorial board of Social Text, whose members interact on a regular basis and who have a generally agreed set of stylistic norms that are reinforced at each meeting. The figure on the left shows that an individual may be a member of a variety of discourse networks whose norms vary. The individual's interaction with these other networks may influence his or her interactions within the tightly-knit discourse network, but is unlikely to have much effect. However, the existence of other networks, and shared memberships of such networks, suggests that no network is intrinsically closed and that all networks are liable to some change, however small.

In my table, I have also indicated that specialist networks have ownership of specialist subgenres, but that these are subsumed into larger genre groupings. So, for example, while Social Text may belong to the subgenre of social philosophy and therefore have particular textual characteristics, it also belongs to the larger genre of academic articles with which it will share some of its characteristics. It may be possible to multiply the hierarchy of genres, but the point of my table is to show that no genre (or 
subgenre) can be impermeable, and that they will all share the characteristics of the larger discourses of which they are a part.

If this is the case, it presents ESP teachers with particular problems. The kinds of genres that are typically part of the ESP syllabus are "schooled" genres par excellence in that they are overtly taught. They, therefore, necessarily belong to the wider discursive practices of education. I have already noted Bhatia's desire to engage with such practices. In this, he may be mindful of the observations of Bourdieu and Passeron (1994: 8) when they write:

In secondary and higher education it is taken for granted that the language of ideas elaborated by the academic and scientific traditions and also the second-order language of allusions and cultural complicities are second nature to intelligent and gifted individuals; or better, that the ability to understand and manipulate these learned languages - artificial languages, par excellence - where we see the natural language of human intelligence at work immediately distinguishes intelligent students from the rest.

The explicit claim here is that the ability to manipulate certain kinds of language is seen as a marker of intelligence, rather than actually being such a marker. Bourdieu and Passeron are therefore suggesting that such a view leads to a kind of "false consciousness" which contributes to social divisiveness. In some academic disciplines (e.g., the natural sciences), the need to master such artificial languages may be a necessary element in grasping the subject matter. In these instances, the intervention of the ESP teacher could be regarded as benign. In other subjects (e.g., business studies, commerce), the agenda is more likely to be overtly ideological. Here it may be appropriate for ESP teachers to consider whether they wish to encourage the discursive practices which grow out of such ideologies.

41 I shall therefore end with the uncomfortable question posed in my title: should we take the socially responsible position of intervening in our students' professional development (or, as Mike Sosteric said: teach them Pomospeak), or should we take the equally socially responsible position of refusing to give succour to the social atomisation that underlies the processes of certain kinds of genre proliferation?

\section{BIBLIOGRAPHY}

Barton, D. 1994. Literacy: An Introduction to the Ecology of Written Language. Oxford: Blackwell.

Bex, T. 1996. Variety in Written English. Texts in Society: Societies in text. London: Routledge.

Bex, T. 1999. "The linguistic study of non-literary genres: The view from the reader". European Journal of English Studies 3, 87-105.

Bex, T. forthcoming. When Discourses Clash: Social Aspects of Meaning. Newcastle, GB: Cambridge Scholars Publishing.

Bhatia, V. K. 1993. Analysing Genre: Language Use in Professional Settings. London: Longman. 
Bhatia, V. K. 2008. "Genre Analysis, ESP and professional practice”. English for Specific Purposes 27, 161-174.

Bourdieu, P. and J.-C. Passeron. 1994. "Language and relationship to language in the teaching situation". In Bourdieu, P., J.-C. Passeron and M. de Saint-Martin (eds.), Academic Discourse (trans. R. Teese). Cambridge: Polity Press, 1-30.

Dudley-Evans, T. and M. J. St. John. 1998. Developments in English for Specific Purposes. A Multidisciplinary Approach. Cambridge: Cambridge University Press.

Foucault, M. 1972. The Archeology of Knowledge. (trans. A. M. Sheridan Smith). London: Routledge. Halliday, M.A.K. 1978. Language as Social Semiotic. London: Edward Arnold.

Halliday, M.A.K. and R. Hasan. 1989. Language, Context and Text: Aspects of language in a socialsemiotic perspective. Oxford: Oxford University Press.

Harris, R. 1998. Introduction to Integrational Linguistics. Oxford: Pergamon Press.

Kramnick, J. B. 1998. Making the English Canon: Print-capitalism and the cultural past, 1700-1770. Cambridge: Cambridge University Press.

Leckie-Tarry, H. 1995. Language and Context: A functional linguistic theory of register. London: Pinter. Martin, J. R. 1992. English Text: System and Structure. Amsterdam: John Benjamins.

Milroy, L. 1987. Language and Social Networks. $2^{\text {nd }}$ ed. Oxford: Blackwell.

Paltridge, B. 1995. "Working with genre: a pragmatic perspective”. Journal of Pragmatics 24, 393-406.

Sokal, A. 1996. “A physicist experiments with cultural studies”. Lingua Franca 6, 62-64.

Sokal, A. and J. Bricmont. 1998. Intellectual Impostures: Postmodern philosophers' abuse of science. London: Profile Books Ltd.

Sokal, A. 2010. Web site, March 2010 <http://www.physics.nyu.edu/sokal/>.

Swales, J. 1971. Writing Scientific English. London: Nelson.

Swales, J. 1990. Genre Analysis. Cambridge: Cambridge University Press.

Swales, J. 1993. “Genre and engagement”. Revue Belge de Philologie et d'Histoire 71, 687-98.

Swales, J. 1996. "Occluded genres in the academy: The case of the submission letter". In Ventola, E. and A. Mauranen (eds.), Academic Writing: Intercultural and Textual Issues. Amsterdam: John Benjamins, 45-58.

Terry, R. 2001. Poetry and the Making of the English Literary Past: 1660-1781. Oxford: Oxford University Press.

Todorov, T. 1976. "The origin of genres". New Literary History 8, 159-70.Image $200000160000005400000054315 E C E A 5$.pctImage 200000160000005400000054 C5BBFEDA.pct

\section{NOTES}

1. 1770 and 1816 respectively.

2. And it is necessarily incomplete, and has been challenged by other scholars, e.g., Terry (2001).

3. I should make it clear that I am only referring to written genres in this paper.

4. The majority of my quotations come from Sokal and Bricmont (1998). 
5. It is worth pointing out that Social Text is not peer reviewed.

6. All postings are taken from Sokal's website <http://www.physics.nyu.edu/sokal>.

7. Posted by Glenn Muschert <mkarim@moses.culver.edu> with permission 19 May 1996.

8. N.B. He does not consider that it may tell something about how philosophers read science.

9. For more on Sokal, see Bex (forthcoming); on parody in general, Bex (1999).

\section{ABSTRACTS}

This paper challenges the ways that genre has been characterised over the last thirty-forty years. It begins by tracing the development of a particular discourse (the growth of "English" literature as a discipline) and shows how difficult it is to delimit the genres associated with such a discourse. It continues by arguing that there have been two dominant characterisations in recent years: one that sees genres in terms of their textual characteristics and one that sees them in terms of their users. It further argues that neither of these characterisations is entirely satisfactory. Textual characteri-sations are subverted by parodies, while ethnographic ones ignore the ways in which users are implicated in wider discursive practices. It concludes by offering a model of the interrelations between genres and discourses and invites ESP teachers to become more self-reflective in their own practices.

Cet article remet en question la notion de genre telle qu'elle a été définie au cours des trente ou quarante dernières années. Après avoir retracé le développement d'un discours particulier (l'émergence de la littérature "anglaise » en tant que discipline), il montre la difficulté à délimiter les genres associés à un tel discours. Il suggère en outre qu'aucune des deux théories du genre dominant la recherche récente n'est entièrement satisfaisante: ni celle qui définit les genres en termes de propriétés textuelles, ni celle qui les analyse en fonction de leurs utilisateurs. Les caractéristiques textuelles peuvent en effet être subverties par les parodies, tandis que les caractérisations ethnographiques ne tiennent pas compte des pratiques discursives plus larges des utilisateurs. Il conclut en proposant un modèle des interrelations entre genres et discours et invite les enseignants d'anglais de spécialité à davantage d'introspection dans leurs pratiques.

\section{INDEX}

Mots-clés: anglais de spécialité, discours, genre, parodie

Keywords: discourse, ESP, genre, parody

\section{AUTHOR}

\section{TONY BEX}

Tony Bex is a retired academic who has taught in the Universities of Algiers, Khartoum, Papua New Guinea and Kent, UK. He was also head of the English Language Unit in Riyadh El-Kharj hospital in Saudi Arabia. His interests are varied, having published in stylistics, English language 
and ELT/ESP. His abiding interest, however, has been in the relationships between written texts and their users. tonybex28@yahoo.co.uk 